\title{
An investigation of the relationship between health literacy and quality of life in pregnant women
}

\section{Gebelerde sağlık okuryazarlığı ile yaşam kalitesi arasındaki ilişkinin incelenmesi}

\author{
Didem ŞİMŞEK KÜÇÜKKELEPÇE ${ }^{1 @(D)}$, Zehra GÖLBAŞI ${ }^{1}$, Nukhet BAYER ${ }^{2}$ (D), Hande \\ AĞIRBAŞ ${ }^{3}$ (D)
}

${ }^{1}$ Lokman Hekim University, Faculty of Health Sciences, Department of Midwifery, 06510, Ankara-Turkey

${ }^{2}$ Lokman Hekim University, Faculty of Health Sciences, Department of Nursing, 06510, Ankara-Turkey

${ }^{3}$ Lokman Hekim University, Etlik Hospital, 06010, Ankara-Turkey

Atıf gösterme/Cite this article as: Şimşek Küçükkelepçe D, Gölbaşı Z, Bayer N, Ağırbaş H. An investigation of the relationship between health literacy and quality of life in pregnant women. ADYÜ Sağllk Bilimleri Derg. 2021;7(3):XX. doi:10.30569.adiyamansaglik.983204

\begin{abstract}
Aim: The research was carried out to determine the relationship between health literacy and quality of life in pregnant women.

Materials and Methods: This analytical crosssectional study was conducted with 219 pregnant women in a private hospital in Ankara. Data were collected through the Turkish Health Literacy Scale-32, the WHOQOL-BREF Quality of Life Scale, and the Socio-demographic Form. Statistical analyses included numbers, percentages, means, standard deviations, Pearson correlation, and linear regression analysis.

Results: In the study, it was determined that the pregnant women had insufficient health literacy $(n=15)$, problematic-limited health literacy $(n=41)$, adequate health $(\mathrm{n}=87)$, and excellent health literacy $(n=76)$. This study found a linear and positive relationship between health literacy and quality of life $(p<0.05)$. In addition, a one-unit increase in the Health Literacy Scale was found to cause an increase in all sub-scales of the Quality-of-Life Scale, and this increase was found to be statistically significant $(p<0.05)$.

Conclusion: As a result of the data obtained from the study, it was determined that there was a positive, and weak relationship between the health literacy level of pregnant women and their quality of life.
\end{abstract}

Keywords: Health literacy; Nursing; Pregnancy; Quality of life.

\begin{abstract}
Öz
Amaç: Araştırma gebelerde sağlık okuryazarlığ́ ile yaşam kalitesi arasındaki ilişkiyi belirmek amacı ile gerçekleştirildi.

Gereç ve Yöntem: Analitik kesitsel nitelikteki bu araştırma, Ankara'da özel bir hastanede 219 gebe ile yürütüldü. Veriler, Türkiye sağlık okuryazarlık ölçeği32, WHOQOL-BREF yaşam kalitesi ölçeği ve Katılımc1 bilgi formu ile topland. İstatistiksel değerlendirmede; sayı, yüzde, ortalama, standart sapma, Pearson korelasyon ve doğrusal regresyon analizi kullanıldi.
\end{abstract}

Bulgular: Araştırmada gebelerin $(n=15)$ yetersiz sağlık okuryazarlığına, $\quad(n=41) \quad$ sorunlu-sınırlı sağlık okuryazarlı̆̆ $1,(n=87)$ yeterli sağlık okuryazarlığ 1 ve $(n=76)$ mükemmel sağlık okuryazarlığına sahip olduğu saptand1. Araştırmada sağlık okuryazarlığı ile yaşam kalitesi arasında doğrusal pozitif ilişki olduğu saptand (r:0,226, $p<0,05)$. Aynı zamanda sağlık okuryazarlık ölçeğinde meydana gelen bir birimlik artışın yaşam kalitesi ölçeğinin tüm alt boyutlarında artışa neden olduğu ve bu artışın istatiksel olarak da anlamlı olduğu saptandi $(p<0,05)$.

Sonuç: Araştırmadan elde edilen veriler sonucunda gebelerin sağlık okuryazarlık düzeyi ile yaşam kalitesi arasında pozitif yönde zayıf düzeyde ilişki olduğu saptand1.

Anahtar Kelimeler: Gebelik; Hemşirelik; Sağlık okuryazarlığı; Yaşam kalitesi.

Yazışma Adresi/Address for Correspondence: Didem ŞIMSŞEK KÜÇÜKKELEPÇE, Lokman Hekim University, Faculty of Health Sciences, Department of Midwifery, 06510, Ankara-Turkey, E-mail: didemkucukkelepce@ gmail.com

Geliş Tarihi/Received:16.08.2021 Kabul Tarihi/Accepted:17.12.2021 Yayım Tarihi/Published online:31.12.2021

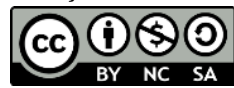

Bu eser, Creative Commons Atıf-GayriTicari 4.0 Uluslararası Lisansı ile lisanslanmıştır.

Telif Hakk1 (C) 2021 Adıyaman Üniversitesi Rektörlüğü 


\section{Introduction}

Health literacy involves all skills related to accessing, understanding, using, appraising, and applying health information to prevent diseases and to promote and improve good health. ${ }^{1}$ This concept also includes an individual's ability to obtain, analyze and understand basic health information and services required for making the right healthrelated decisions. ${ }^{2}$ Research reports a highly significant relationship between health literacy and health behaviors. ${ }^{3-5}$ Low health literacy could cause a decrease in self-care and an increase in morbidity and mortality. ${ }^{6}$ Health literacy is closely associated with not only the individual's own health but also the health of other family members and society. ${ }^{7}$ When the effect of women's health on the health of the baby, children, and the family is taken into consideration, it could be concluded that women's health literacy is an important issue for community health. Hence, women's health literacy level is reported to be an important factor in terms of demonstrating skills that protect and improve both their own health and the health of their children. ${ }^{1,8}$

However, almost $16 \%$ of the adult population in the world does not have the basic literacy skills, and 2/3 of this population is composed of women. ${ }^{9}$ Women who lack the basic literacy skills are also considered to lack health literacy at the desired level. This condition could be a factor that leads to maternal and children's health problems especially in reproductive age. Health literacy levels of women at reproductive age play an important role in their decisions about receiving healthcare in the pregnancy and breastfeeding periods. Gaining healthy lifestyle behaviors in this period has positive effects on the course of pregnancy and the health of the fetus. Therefore, together with the health literacy level, pregnant women's access to health information and effective use of it has a crucial role in increasing quality of life. ${ }^{10,11}$

Quality of life includes individuals' physical, psychological, and social perceptions. Although pregnancy is not considered a pathological condition, women's quality of life could be affected negatively by the physiological changes and the discomfort caused by these changes. ${ }^{12}$ Studies show that complaints such as nausea and vomiting, stomach problems, or back pain experienced during pregnancy have negative effects on quality of life. ${ }^{13-15}$ These kinds of complaints that are experienced during pregnancy and that have negative effects on quality of life demonstrate differences according to pregnant women's healthy lifestyle behaviors. Nutrition, exercise, interpersonal relationships, health responsibility, and avoiding unhealthy behaviors have positive effects on both pregnancy and general health. Healthy lifestyle behaviors could be associated with health literacy levels. ${ }^{10,16,17}$ Although the literature includes various studies on quality of life and health literacy during pregnancy, it includes no studies that investigated the relationship between health literacy and quality of life in the pregnancy period. ${ }^{1,2,12,13,15}$ In light of this information, this study aims to identify the relationship between health literacy and quality of life in pregnant women.

\section{Research questions}

1. What is the health literacy level of pregnant women?

2. What are the quality of life levels of pregnant women?

3. Is there a relationship between health literacy and quality of life in pregnant women?

\section{Materials and Methods}

\section{The type of the study}

This study utilized the cross-sectional research method, one of the analytical research methods, was used.

\section{The universe and sample of the research}

This study was conducted in a private hospital in Ankara. Convenience sampling method was utilized, and the study included pregnant women who were came to the gynecology polyclinic of the hospital for routine follow-ups and/or examination.

Data were collected between February and June 2019. The purpose of the study was 
explained to the pregnant women who were invited to participate in the study, and data collection forms were given to the pregnant women who agreed to participate in the study and they were provided to fill in. Thus, the sample of the study consisted of 219 pregnant women who volunteered to participate in the study and met the inclusion criteria. Inclusion criteria were to have a healthy pregnancy and be over the age of 18. Exclusion criteria were having a twin pregnancy, having a high-risk pregnancy and not volunteering to participate in the study

\section{Data collection tools}

Data were collected through the Turkish Health Literacy Scale-32, WHOQOL-BREF Quality of Life Scale, and the Sociodemographic Form developed by the researchers to identify pregnant women's socio-demographic features.

\section{The Socio-demographic form}

The form developed by the researchers is composed of 13 questions regarding the participants' characteristics such as age, gender, marital status, and pregnancy-related characteristics such as the gestational week and the number of pregnancies. .,2,12,15 $^{2}$

\section{Turkish Health Literacy Scale (THLS-32)}

Okyay, Abacigil and Harla (2012) developed the scale and performed its reliability and validity. The scale has 32 questions and two sub-scales (Treatment and Service and Protection from Diseases/Improvement of Health). The scale is rated on a 5-point Likert scale that includes 1: "very easy", 2: "easy", 3: "difficult", 4: "very difficult", and 5: "no idea" options. The scale is calculated using the index $=($ mean- 1$)$ $x(50 / 3)$ formula, and it was standardized between 0 and 50, which indicated that 0 was the lowest health literacy level and 50 was the highest. The score that is obtained is classified into four categories. Health literacy scores of 0-25 points indicate inadequate health literacy, $>25-33$ points indicate problematic - limited health literacy, >33-42 points indicate adequate health literacy, and $>42-50$ points indicate excellent health literacy. The sub-dimensions of the Turkish
Health Literacy Scale (THLS-32) constitute the independent variables of the study. The Health Literacy Scale, for this study, Treatment and service (0.920) and Protection from Diseases and Improvement of Health sub-scales (0.942), also has high reliability.

\section{WHOQOL-BREF Quality-of-Life Scale}

The Quality-of-Life Scale- Brief Form was developed by the World Health Organization (WHO), and the Turkish reliability and validity of the form (WHOQOL BREF-TR) were performed by Eser et al. The scale measures bodily, psychological, social, and environmental well-being and is composed of 26 questions. The Turkish version has 27 questions, and the $27^{\text {th }}$ question is a national question called "Environment-TR". Increased scores indicate higher quality of life. ${ }^{18}$ The sub-dimensions of the WHOQOL BREF-TR scale constitute the dependent variables of the study. For this study Psychological and Environment-TR sub-scales of the WHOQOL-BREF Quality of Life Scale have high reliability $(0.804,0.821$ respectively). Cronbach's alfa coefficients of the Physical Health sub-scale and Social Relationships sub-scale were calculated as 0.781 and 0.774 respectively, indicating very high reliability.

\section{Data analysis}

Data were collected by the researchers after the pregnant women were given information about the study and invited to participate. Consent was received from the pregnant women who agreed to participate in the study, they were administered the data collection forms, and the data collection forms were collected back by the researchers. Data were analyzed using Statistical Package for the Social Sciences Statistics 20 package program (SPSS 20). After it was found that the data distributed normally by Kolmogorov Simirnov, analyses included means, standard deviations, numbers, percentages, $\chi 2$ : Chisquare, Kruskal Wallis, Pearson correlation analysis, and linear regression analysis.

\section{Ethical aspect of the research}

Ethics committee approval was obtained from Lokman Hekim University Noninvasive Clinical Research Ethics Committee 
Health literacy and quality of life in pregnant women.

(Code No.2020011- Decision No. 2020/013). Permission was obtained from the institution where the research was conducted. In addition, the purpose of the study was explained to the pregnant women who agreed to participate in the study, and verbal consent was obtained from the pregnant women.

\section{Limitations of the Study}

The data obtained in this study were limited to the views of pregnant women who visited or were hospitalized in the pregnancy polyclinic of a private hospital in Ankara. In addition, it is limited to self-report of the scales used in the research.

\section{Results}

Table 1 demonstrates the distribution of the socio-demographic characteristics of pregnant women. The average age of the participating pregnant women was
Şimşek Küçükkelepçe D, Gölbaşı Z, Bayer N, Ağırbaş H.

28.69 $\pm 4.86(\min : 19-\max : 43)$. Of all the participants, $38.81 \%$ graduated from high school, $50.68 \%$ graduated from university, and $44.29 \%$ worked. More than half of the partners graduated from university $(57.99 \%)$.

The majority of the participating pregnant women $(66.67 \%)$ had income equal to expenses, $86.76 \%$ lived in the city center, and majority of them $(88.13 \%)$ had a nuclear family. Data about the obstetric history of the participants and their current pregnancy indicated that the average number of pregnancies was $1.86 \pm 1.17$, the average number of living children was $1.32 \pm 0.99$ and $79.45 \%$ had a planned pregnancy, and the average gestational week was $32.44 \pm 8.36$ weeks. Of all the participants $52.97 \%$ had health follow-ups before pregnancy, and 9.13\% had a health problem during pregnancy (Table 1).

Table 1. Distribution of the socio-demographic characteristics of the pregnant women $(n=219)$

\begin{tabular}{|c|c|c|}
\hline Variables & Number (n) & Percentage (\%) \\
\hline \multicolumn{3}{|l|}{ Education level } \\
\hline Literate/ Primary school & 7 & 3.19 \\
\hline Secondary school & 16 & 7.31 \\
\hline High School & 85 & 38.81 \\
\hline University & 111 & 50.68 \\
\hline \multicolumn{3}{|l|}{ Working or not } \\
\hline Yes & 97 & 44.29 \\
\hline No & 122 & 55.71 \\
\hline \multicolumn{3}{|l|}{ Partner's education level } \\
\hline Literate/ Primary school & 5 & 2.28 \\
\hline Secondary school & 10 & 4.57 \\
\hline High School & 77 & 35.16 \\
\hline University & 127 & 57.99 \\
\hline \multicolumn{3}{|l|}{ Income level } \\
\hline Income less than expenses & 26 & 11.87 \\
\hline Income equal to expenses & 146 & 66.67 \\
\hline Income more than expenses & 47 & 21.46 \\
\hline \multicolumn{3}{|l|}{ Place of living } \\
\hline City & 190 & 86.76 \\
\hline District & 28 & 12.79 \\
\hline Town/Village & 1 & 0.46 \\
\hline \multicolumn{3}{|l|}{ Family Type } \\
\hline Nuclear Family & 193 & 88.13 \\
\hline Extended Family & 26 & 11.87 \\
\hline \multicolumn{3}{|l|}{ Having a planned pregnancy } \\
\hline Yes & 174 & 79.45 \\
\hline No & 45 & 20.55 \\
\hline \multicolumn{3}{|c|}{ Having health follow-ups before pregnancy } \\
\hline Yes & 116 & 52.97 \\
\hline No & 103 & 47.03 \\
\hline \multicolumn{3}{|c|}{ Presence of a health problem that developed with pregnancy } \\
\hline Yes & 20 & 9.13 \\
\hline No & 199 & 90.87 \\
\hline
\end{tabular}




\begin{tabular}{|c|c|c|}
\hline \multicolumn{3}{|c|}{ Presence of a health problem related to the baby } \\
\hline Yes & 5 & 2.28 \\
\hline No & 214 & 97.72 \\
\hline & \multicolumn{2}{|c|}{ Mean \pm SD } \\
\hline Age & \multicolumn{2}{|c|}{$28.69 \pm 4.86$} \\
\hline Number of Pregnancies & \multicolumn{2}{|c|}{$1.86 \pm 1.17$} \\
\hline Number of Living Children & \multicolumn{2}{|c|}{$1.32 \pm 0.99$} \\
\hline Current Gestational Week & \multicolumn{2}{|c|}{$32.44 \pm 8.36$} \\
\hline \multicolumn{3}{|l|}{ WHOQOL-BREF } \\
\hline Physical Health & \multirow{2}{*}{\multicolumn{2}{|c|}{$\frac{24.62 \pm 4.63}{22.50 \pm 3.67}$}} \\
\hline Psychological & & \\
\hline Social Relationships & \multicolumn{2}{|c|}{$11.48 \pm 2.33$} \\
\hline Environment-TR & \multicolumn{2}{|c|}{$32.89 \pm 5.04$} \\
\hline Turkish Health Literacy Scale (THLS-32) & \multicolumn{2}{|c|}{$37.91 \pm 8.14$} \\
\hline Treatment and Service & \multicolumn{2}{|c|}{$38.29 \pm 8.13$} \\
\hline $\begin{array}{l}\text { Protection from Diseases and } \\
\text { Improvement of Health }\end{array}$ & \multicolumn{2}{|c|}{$37.52 \pm 9.26$} \\
\hline
\end{tabular}

The evaluation of THLS-32 classifications according to the characteristics of individuals is given in Table 3. There is a statistically significant difference in THLS-32 classifications in terms of age, education level, co-educational status and current week of gestation $(p<0.05)$. The median age of those with problematic-limited health literacy was higher than the median of adequate health literacy $(p=0.017)$. As education and coeducational status increases, the percentage of those with adequate and excellent health literacy increases $(p=0.001)$. The median gestational week of those with insufficient health literacy and the median of gestational week of those with excellent health literacy were lower $(p=0.003)$ (Table 2$)$.

Table 2. Evaluation of THLS-32 Classifications According to Socio-demographic Characteristics of Pregnant Women's $\underline{(n=219) .}$

\begin{tabular}{|c|c|c|c|c|c|}
\hline \multirow[b]{2}{*}{ Variables } & \multicolumn{4}{|c|}{ Turkish Health Literacy Scale Classifications } & \multirow[b]{2}{*}{$\begin{array}{c}\text { Test value } \\
\text { and } \\
p \text { value }\end{array}$} \\
\hline & $\begin{array}{c}\text { Inadequate } \\
\text { Health Literacy } \\
\qquad \mathbf{n}=15\end{array}$ & $\begin{array}{c}\text { Problematic- } \\
\text { Limited Health } \\
\text { Literacy } \\
n=41\end{array}$ & $\begin{array}{l}\text { Adequate Health } \\
\text { Literacy } n=87\end{array}$ & $\begin{array}{c}\text { Excellent Health } \\
\text { Literacy } \\
n=76\end{array}$ & \\
\hline Age* $^{*}$ & $\begin{array}{l}27.20 \pm 5.26 \\
\quad(20-40)\end{array}$ & $\begin{array}{c}28.69 \pm 4.85 \\
(18-43)^{\mathrm{a}} \\
\end{array}$ & $\begin{array}{c}28.14 \pm 4.50 \\
(18-43)^{\mathrm{a}}\end{array}$ & $\begin{array}{c}28.55 \pm 4.49 \\
(20-41)\end{array}$ & $\begin{array}{l}\mathrm{F}=3.191 \\
p=0.025\end{array}$ \\
\hline \multicolumn{5}{|l|}{ Education level } & \multirow{4}{*}{$\begin{array}{l}\chi^{2}=22.959 \\
p=0.001\end{array}$} \\
\hline $\begin{array}{l}\text { Literate/ Primary } \\
\text { school }\end{array}$ & $6(26.09 \%)$ & $4(17.39 \%)$ & $9(39.13 \%)$ & $4(17.39 \%)$ & \\
\hline Secondary school & $8(9.41 \%)$ & $17(20 \%)$ & $34(40 \%)$ & $26(30.59 \%)$ & \\
\hline High School & $1(0.9 \%)$ & $20(18.02 \%)$ & $44(39.64 \%)$ & $46(41.44 \%)$ & \\
\hline \multicolumn{5}{|l|}{ Working or not } & \multirow{3}{*}{$\begin{array}{l}\chi^{2}=3.297 \\
p=0.348\end{array}$} \\
\hline Yes & $6(6.19 \%)$ & $16(16.49 \%)$ & $35(36.08 \%)$ & $40(41.24 \%)$ & \\
\hline No & $9(7.38 \%)$ & $25(20.49 \%)$ & $52(42.62 \%)$ & $36(29.51 \%)$ & \\
\hline \multicolumn{5}{|l|}{ Partner's education level } & \multirow{4}{*}{$\begin{aligned} \chi^{2} & =23.237 \\
p & =0.001\end{aligned}$} \\
\hline $\begin{array}{l}\text { Literate/ Primary } \\
\text { school }\end{array}$ & $4(26.7 \%)$ & $4(26.7 \%)$ & $5(33.3 \%)$ & $2(13.3 \%)$ & \\
\hline Secondary school & $8(10.4 \%)$ & $18(23.4 \%)$ & $32(41.6 \%)$ & $19(24.7 \%)$ & \\
\hline High School & $3(2.4 \%)$ & $19(15 \%)$ & $50(39.4 \%)$ & $55(43.3 \%)$ & \\
\hline \multicolumn{5}{|l|}{ University } & \multirow{4}{*}{$\begin{array}{l}\chi^{2}=4.551 \\
p=0.603\end{array}$} \\
\hline Income level & $2(7.69 \%)$ & $7(26.92 \%)$ & $8(30.77 \%)$ & $9(34.62 \%)$ & \\
\hline $\begin{array}{l}\text { Income less than } \\
\text { expenses }\end{array}$ & $11(7.53 \%)$ & $27(18.49 \%)$ & $62(42.47 \%)$ & $46(31.51 \%)$ & \\
\hline $\begin{array}{l}\text { Income equal to } \\
\text { expenses }\end{array}$ & $2(4.26 \%)$ & $7(14.89 \%)$ & $17(36.17 \%)$ & $21(44.68 \%)$ & \\
\hline \multicolumn{5}{|l|}{ Place of living } & \multirow{3}{*}{$\begin{array}{l}\chi^{2}=7.703 \\
p=0.053\end{array}$} \\
\hline City & $11(5.79 \%)$ & $34(17.89 \%)$ & $73(38.42 \%)$ & $72(37.89 \%)$ & \\
\hline District/Town/Village & $4(13.79 \%)$ & $7(24.14 \%)$ & $14(48.28 \%)$ & $4(13.79 \%)$ & \\
\hline
\end{tabular}




\begin{tabular}{|c|c|c|c|c|c|}
\hline \multicolumn{5}{|l|}{ Family Type } & \multirow{3}{*}{$\begin{array}{c}\chi^{2}=7.072 \\
p=0.070\end{array}$} \\
\hline Nuclear Family & $11(5.7 \%)$ & $36(18.65 \%)$ & $74(38.34 \%)$ & $72(37.31 \%)$ & \\
\hline Extended Family & $4(15.38 \%)$ & $5(19.23 \%)$ & $13(50 \%)$ & $4(15.38 \%)$ & \\
\hline $\begin{array}{l}\text { Number of } \\
\text { Pregnancies* }\end{array}$ & $2(1-4)$ & $2(1-6)$ & $1(1-6)$ & $1(1-5)$ & $\begin{array}{l}\mathrm{K}=5.298 \\
p=0.151\end{array}$ \\
\hline $\begin{array}{l}\text { Number of Living } \\
\text { Children* }\end{array}$ & $1(0-4)$ & $1(0-4)$ & $1(0-4)$ & $1(0-4)$ & $\begin{array}{l}\mathrm{K}=5.018 \\
p=0.171\end{array}$ \\
\hline \multicolumn{5}{|c|}{ Having a planned pregnancy } & \multirow{3}{*}{$\begin{array}{l}\chi^{2}=1.830 \\
p=0.608\end{array}$} \\
\hline Yes & $10(5.75 \%)$ & $32(18.39 \%)$ & $71(40.8 \%)$ & $61(35.06 \%)$ & \\
\hline No & $5(11.11 \%)$ & $9(20 \%)$ & $16(35.56 \%)$ & $15(33.33 \%)$ & \\
\hline \multicolumn{5}{|c|}{ Having health follow-ups before pregnancy } & \multirow{3}{*}{$\begin{array}{l}\chi^{2}=7.380 \\
p=0.061\end{array}$} \\
\hline Yes & $6(5.17 \%)$ & $16(13.79 \%)$ & $46(39.66 \%)$ & $48(41.38 \%)$ & \\
\hline No & $9(8.74 \%)$ & $25(24.27 \%)$ & $41(39.81 \%)$ & $28(27.18 \%)$ & \\
\hline $\begin{array}{l}\text { Current Gestational } \\
\text { Week* }\end{array}$ & $24(12-39)^{a}$ & $34(10-40)$ & $36(9-40)$ & $38(12-41)^{\mathrm{a}}$ & $\begin{array}{c}\mathrm{K}=13.780 \\
p=0.003\end{array}$ \\
\hline \multicolumn{5}{|c|}{ Presence of a health problem that developed with pregnancy } & \multirow{3}{*}{$\begin{array}{l}\chi^{2}=5.983 \\
p=0.112\end{array}$} \\
\hline Yes & $0(0 \%)$ & $7(35 \%)$ & $6(30 \%)$ & $7(35 \%)$ & \\
\hline No & $15(7.54 \%)$ & $34(17.09 \%)$ & $81(40.7 \%)$ & $69(34.67 \%)$ & \\
\hline
\end{tabular}

*expressed as mean (minimum-maximum).

$\chi 2$ : Chi-square test statistic, $\mathrm{K}=$ Kruskal Wallis test statistic, letter indices show different groups.

The analysis of the relationship of the scales with each other indicated a linear, positive, and weak relationship between the Physical Health sub-scale of the WHOQOLBREF scale and Health Literacy Scale total score and protection from diseases and improvement of health, accessing information, understanding information, appraising information, and using/applying information sub-scales $(p<0.05)$. In addition, a linear, positive, and very weak relationship was found between the Physical Health subscale of the WHOQOL-BREF scale and treatment and service, appraising information, and using/applying information sub-scales $(p<0.05)$ (Table 3).

Table 3. Relationship between Pregnant Women's Quality of Life and Health Literacy $(n=219)$

\begin{tabular}{|c|c|c|c|c|c|}
\hline \multirow{3}{*}{\multicolumn{2}{|c|}{ Scales }} & \multicolumn{4}{|c|}{ WHOQOL-BREF Quality of Life Scale } \\
\hline & & Physical health & Psychological & $\begin{array}{c}\text { Social } \\
\text { Relationships }\end{array}$ & Environment-TR \\
\hline & & $\mathbf{r} / p$ & $\mathbf{r} / p$ & $\mathbf{r} / p$ & $\mathbf{r} / p$ \\
\hline \multirow{3}{*}{ 至 } & Health Literacy (THLS-32) & $0.226 / 0.001$ & $0.333 / 0.001$ & $0.128 / \mathbf{0 . 0 5 8}$ & $0.325 / 0.001$ \\
\hline & Treatment and Service & $0.153 / 0.023$ & $0.302 / 0.001$ & $0.140 / 0.039$ & $0.330 / 0.001$ \\
\hline & $\begin{array}{l}\text { Protection from diseases and } \\
\text { Improvement of Health }\end{array}$ & $0.264 / 0.001$ & $0.319 / 0.001$ & $0.103 / 0.128$ & $0.282 / 0.001$ \\
\hline
\end{tabular}

Evaluations according to WHOQOLBREF Quality of Life Scale and THLS-32 classification are given in Table 4. Physical health sub-dimension score medians of those with adequate and excellent health literacy were higher than the median score of those with problematic-limited health literacy $(p=0.001)$. The psychological sub-dimension score median of those with perfect health literacy was higher than the median score of those in other THLS-32 classes $(p<0.001)$. Those with excellent health literacy had a higher median score for the Environment-TR sub-dimension than those for problematiclimited health literacy and adequate health literacy $(p<0.001)$.
A linear, positive, and medium-level relationship was found between the psychological sub-scale of the WHOQOLBREF scale and the health literacy scale total score, treatment and service, using/applying information, protection from diseases and improvement of health, using/applying information $(p<0.05)$. Besides, a linear, positive, and weak relationship was found between the psychological sub-scale of the WHOQOL-BREF scale and treatment and service-accessing information, appraising information, protection from diseases and improvement of health-accessing information and understanding information sub-scales $(p<0.05)$. A linear, positive, and weak relationship was found between the 
psychological sub-scale of the WHOQOLBREF scale and the treatment and service- understanding information sub-scale $(r=0.187 ; p<0.05)$.

Table 4. Evaluation of WHOQOL-BREF Quality of Life Scale and THLS-32 Classifications (n=219)

\begin{tabular}{|c|c|c|c|c|c|}
\hline \multirow[b]{2}{*}{$\begin{array}{l}\text { WHOQOL- } \\
\text { BREF Quality of } \\
\text { Life Scale }\end{array}$} & \multicolumn{4}{|c|}{ Health Literacy (THLS-32) Classifications } & \multirow[b]{2}{*}{$\begin{array}{l}\text { Test value } \\
\text { and } \\
\text { p value }\end{array}$} \\
\hline & $\begin{array}{c}\text { Inadequate } \\
\text { Health } \\
\text { Literacy } n=15\end{array}$ & $\begin{array}{c}\text { Problematic- } \\
\text { Limited Health } \\
\text { Literacy } \\
\text { n=41 }\end{array}$ & $\begin{array}{c}\text { Adequate Health } \\
\text { Literacy } n=87\end{array}$ & $\begin{array}{c}\text { Excellent } \\
\text { Health Literacy } \\
\mathrm{n}=76\end{array}$ & \\
\hline Physical health & $25(9-33)$ & $22(15-30)^{\text {a.b }}$ & $26(12-33)^{\mathrm{a}}$ & $25(16-35)^{b}$ & $K=15.703 p=0.001$ \\
\hline Psychological & $22(17-24)^{\mathrm{a}}$ & $21(14-29)^{b}$ & $22(13-29)^{\mathrm{c}}$ & $24(9-30)^{\text {a.b.c }}$ & $\mathrm{K}=26.477 p<0.001$ \\
\hline $\begin{array}{l}\text { Social } \\
\text { Relationships }\end{array}$ & $12(7-15)$ & $11(6-14)$ & $12(6-15)$ & $12(4-15)$ & $\mathrm{K}=7.829 \mathrm{p}=0.050$ \\
\hline Environment-TR & $32(23-41)$ & $30(23-39)^{a}$ & $33(22-41)^{\mathrm{b}}$ & $35.5(17-45)^{\mathrm{a} . \mathrm{b}}$ & $\mathrm{K}=24.00 p<0.001$ \\
\hline
\end{tabular}

A linear, positive, and weak relationship was found between the social relationships sub-scale of the WHOQOL-BREF scale and treatment and service, appraising information, using/applying information, protection from diseases and improvement of healthusing/applying information sub-scales $(p<0.05)$.

A linear, positive, and medium-level relationship was found between the environment sub-scale of the WHOQOLBREF scale and the health literacy scale total score, treatment and service, appraising information, using/applying information, protection from diseases and improvement of health- using/applying information $(p<0.05)$.

A linear, positive, and weak relationship was found between the environment sub-scale of the WHOQOL-BREF scale and treatment and service-accessing information, understanding information, protection from diseases and improvement of health, accessing information, understanding information and appraising information subscales $(p<0.05)$ (Table2).

Table 5 shows the simple linear regression analysis results of the effects of the Health Literacy Scale and sub-scales on the WHOQOL-BREF Quality-of-Life scale. An analysis of the Physical health sub-scale on the health literacy scale and sub-scales one by one showed that the Health Literacy Scale explained $4.7 \%$ of the Physical Health subscale; Treatment and Service sub-scale explained $1.9 \%$ of the Physical Health subscale; and Protection from Diseases and
Improvement of Health sub-scale explained $6.5 \%$ of the Physical Health sub-scale. A oneunit increase in the Health Literacy Scale caused a 0.129-unit increase in the Physical Health sub-scale. A one-unit increase in the Treatment and Service sub-scale caused a 0.087-unit increase in the Physical Health sub-scale. A one-unit increase in the Protection from Diseases and Improvement of Health sub-scale caused a 0.132-unit increase in the Physical Health sub-scale.

An analysis of the Psychological sub-scale of the Health Literacy Scale and sub-scales one by one indicates that the Health Literacy Scale explained $10.6 \%$ of the Psychological sub-scale; Treatment and Service sub-scale explained $8.7 \%$ of the Psychological subscale, and Protection from Diseases and Improvement of Health sub-scale explained $9.8 \%$ of the Psychological sub-scale. A oneunit increase in the Health Literacy Scale caused a 0.150-unit increase in the Psychological sub-scale. A one-unit increase in the Treatment and Service sub-scale caused a 0.136-unit increase in the psychological sub-scale. A one-unit increase in the Protection from Diseases and Improvement of Health sub-scale caused a 0.126-unit increase in the Psychological sub-scale.

When the effects of the Social Relationship sub-scale of the Health Literacy Scale and sub-scales were analyzed, the Health Literacy Scale explained $1.2 \%$ of the Social Relationships sub-scale and the Treatment and Service sub-scale explained $1.5 \%$ of the Social Relationships sub-scale. A one-unit increase in the Health Literacy Scale caused a 
0.037-unit increase in the Social Relationships sub-scale. A one-unit increase in the Treatment and Service sub-scale caused a 0.040-unit increase in the Social Relationships sub-scale.

Table 5. Effect of the Health Literacy Scale and Sub-scales on the WHOQOL-BREF Quality of Life Scale (Simple Linear Regression)

\begin{tabular}{|c|c|c|c|c|c|c|c|c|}
\hline \multirow{2}{*}{$\begin{array}{l}\text { Dependen } \\
\text { t Variable }\end{array}$} & \multirow{2}{*}{$\begin{array}{l}\text { Independent } \\
\text { Variables }\end{array}$} & \multicolumn{2}{|c|}{$\begin{array}{c}\text { Non-standardized } \\
\text { coefficient }\end{array}$} & \multirow{2}{*}{$\begin{array}{c}\begin{array}{c}\text { Standardized } \\
\text { coefficient }\end{array} \\
\text { Beta }\end{array}$} & \multirow{2}{*}{$\mathrm{t}$} & \multirow{2}{*}{$p$} & \multirow{2}{*}{$\mathrm{F}$} & \multirow{2}{*}{ Corrected $\mathrm{R}^{2}$} \\
\hline & & $\mathrm{B}$ & $\begin{array}{l}\text { Standard } \\
\text { Error }\end{array}$ & & & & & \\
\hline \multirow{6}{*}{ 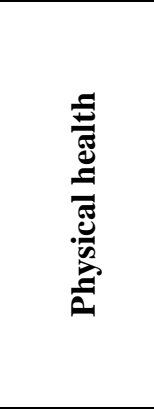 } & Constant & 19.737 & 1.458 & & 13.534 & $<0.001$ & \multirow{2}{*}{11.729} & \multirow{2}{*}{0.047} \\
\hline & Health Literacy & 0.129 & 0.038 & 0.226 & 3.425 & 0.001 & & \\
\hline & Constant & 21.283 & 1.495 & & 14.233 & $<0.001$ & \multirow{2}{*}{5.208} & \multirow{2}{*}{0.019} \\
\hline & Treatment and service & 0.087 & 0.038 & 0.153 & 2.282 & 0.023 & & \\
\hline & Constant & 19.675 & 1.265 & & 15.551 & $<0.001$ & & \\
\hline & $\begin{array}{l}\text { Protection from } \\
\text { diseases and } \\
\text { Improvement of } \\
\text { Health }\end{array}$ & 0.132 & 0.033 & 0.264 & 4.026 & $<0.001$ & 16.207 & 0.065 \\
\hline \multirow{6}{*}{ 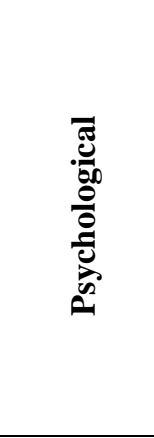 } & Constant & 16.812 & 1.119 & & 15.020 & $<0.001$ & \multirow{2}{*}{26.983} & \multirow{2}{*}{0.106} \\
\hline & Health Literacy & 0.150 & 0.029 & 0.333 & 5.195 & $<0.001$ & & \\
\hline & Constant & 17.274 & 1.143 & & 15.108 & $<0.001$ & \multirow[b]{2}{*}{21.809} & \multirow[b]{2}{*}{0.087} \\
\hline & $\begin{array}{l}\text { Treatment and } \\
\text { Service }\end{array}$ & 0.136 & 0.029 & 0.302 & 4.670 & $<0.001$ & & \\
\hline & Constant & 17.752 & 0.985 & & 18.016 & $<0.001$ & & \\
\hline & $\begin{array}{l}\text { Protection from } \\
\text { Diseases and } \\
\text { Improvement of } \\
\text { Health }\end{array}$ & 0.126 & 0.025 & 0.319 & 4.960 & $<0.001$ & 24.604 & 0.098 \\
\hline \multirow{2}{*}{ 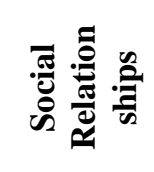 } & Constant & 9.946 & 0.754 & & 13.185 & $<0.001$ & \multirow{2}{*}{4.318} & \multirow{2}{*}{0.015} \\
\hline & $\begin{array}{l}\text { Treatment and } \\
\text { Service }\end{array}$ & 0.040 & 0.019 & 0.140 & 2.078 & 0.039 & & \\
\hline \multirow{6}{*}{ 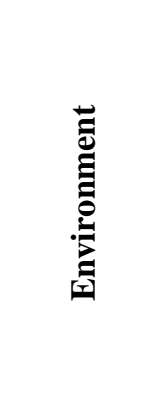 } & Constant & 25.255 & 1.541 & & 16.394 & $<0.001$ & \multirow{2}{*}{25.693} & \multirow{2}{*}{0.102} \\
\hline & Health Literacy & 0.201 & 0.040 & 0.325 & 5.069 & $<0.001$ & & \\
\hline & Constant & 25.064 & 1.554 & & 16.126 & $<0.001$ & \multirow{2}{*}{26.493} & \multirow{2}{*}{0.105} \\
\hline & Treatment and service & 0.204 & 0.040 & 0.330 & 5.147 & $<0.001$ & & \\
\hline & Constant & 27.128 & 1.369 & & 19.815 & $<0.001$ & & \\
\hline & $\begin{array}{l}\text { Protection from } \\
\text { diseases and } \\
\text { Improvement of } \\
\text { Health }\end{array}$ & 0.154 & 0.035 & 0.282 & 4.334 & $<0.001$ & 18.787 & 0.075 \\
\hline
\end{tabular}

When the effects of the Environment subscale of the Health Literacy Scale and subscales were analyzed one by one, the Health Literacy Scale explained $10.2 \%$ of the Environment sub-scale, the Treatment and Service sub-scale explained $10.5 \%$ of the Environment sub-scale, and Protection from Diseases and Improvement of Health subscale explained $7.5 \%$ of the Environment subscale.

A one-unit increase in the Health Literacy sub-scale caused a 0.201-unit increase in the
Environment sub-scale. A one-unit increase in the Treatment and Service sub-scale caused a 0.204-unit increase in the Environment subscale. A one-unit increase in the Protection from Diseases and Improvement of Health sub-scale caused a 0.154-unit increase in the Environment sub-scale.

\section{Discussion}

This study, which investigated the relationship between health literacy levels and quality of life of pregnant women, revealed that health literacy level is associated with 
quality of life during pregnancy. Of all the participants in this study, $52.97 \%$ were found to seek treatment in a health institution before pregnancy. This finding is considered to be associated with the fact that more than half of the participating pregnant women graduated from university. In their study conducted with 139 women who had low health literacy, Fransen et al. reported that only $25 \%$ of women heard about preconception counseling. ${ }^{19}$ This finding indicates that women who had low health literacy levels also had inadequate knowledge and awareness about preconception counseling. The majority of the pregnant women in this study $(79.45 \%)$ indicated that they had a planned pregnancy. Another study on the issue reported that $20 \%$ of the pregnant women had unplanned pregnancy. ${ }^{20}$ Although the ratio of planned pregnancies was high, it seems that one every five women had an unplanned pregnancy. This finding suggests that pregnancies without preconception counseling could be associated with pregnant women's low health literacy levels. There is a relationship between health literacy levels and health perception, and this affects decisions about receiving health services and choosing the right services. $^{20-22}$ Although pregnancy is a physiological process, pregnant women's quality of life is affected by factors such as limitations in physical activities, emotional changes, parity, gestational week, and having a planned pregnancy. ${ }^{23-25}$ Studies in the literature show that health literacy level is also one of the factors affecting quality of life. ${ }^{26-28}$

When the relationship between pregnant women's health literacy level and quality of life was analyzed, a linear and positive relationship was detected between the Physical Health sub-scale of the Quality-ofLife Scale and the Health Literacy Scale total score and Protection from Diseases and Improvement of Health, Accessing Information, Understanding Information, Appraising Information and Using/Applying Information sub-scales. A study that investigated the relationship between menopausal woman's health literacy on their quality of life showed that health literacy affected quality of life. ${ }^{28}$ A study conducted with women who had breast cancer reported that health literacy affected both quality of life and the experience of anxiety. ${ }^{29}$ Another study reported that women who had low health literacy levels were 1.33 times more at risk in terms of having a chronic disease and they experienced more pain in comparison to women who had high health literacy levels. ${ }^{30}$ The literature includes studies on the relationship between health literacy level and quality of life in various fields. Data obtained from this study show that a one-unit increase in the Health Literacy Scale caused a 0.129unit increase in the Physical Health subscale, a 0.150-unit increase in the Psychological sub-scale, a 0.037-unit increase in the Social Relationships sub-scale, and a 0.201-unit increase in the Environment TR sub-scale, and health literacy was found to affect the quality of life. This finding indicates that women's health literacy affected their quality of life under all conditions.

In conclusion, data obtained from this study showed that pregnant women's health literacy level affected quality of life. In line with these findings, it is recommended that starting from the preconception period, women should be provided with awarenessraising trainings on how to access, use, and appraise accurate health information.

\section{Ethics Committee Approval}

The study protocol was approved by Ethics committee of Lokman Hekim University Non-invasive Clinical Research Ethics Committee (Code No.2020011- Decision No. 2020/013).

\section{Informed Consent}

All participants signed the Informed Consent Form and their consent was obtained.

\section{Author contributions}

Conception-D.Ş.K, N.B. Z. G. DesignD.Ş.K, N.B. Supervision-D.Ş.K; MaterialsD.Ş.K, N.B. Data Collection-H.A., N.B. Analysis and/or Interpretation- D.Ş.K, N.B. Literature review- D.Ş.K, N.B. Critical Review-D.Ş.K, N.B. Z. G.

\section{Acknowledgments}


We thank all the participants who agreed to participate in the research for their sincere sharing.

\section{Conflict of Interest}

No conflict of interest was declared by the authors.

\section{Financial Disclosure}

The authors declared that this study has received no financial support.

\section{Statements}

These research results have not previously been presented.

\section{Peer-review}

\section{Externally peer-reviewed.}

\section{Reference}

1. Zibellini, J., Muscat, D. M., Kizirian, N., \& Gordon, A. Effect of health literacy interventions on pregnancy outcomes: A systematic review. Women and Birth. 2021;34(2):180-186 doi:10.1016/j.wombi.2020.01.010

2. Dadipoor, S., Ramezankhani, A., Alavi, A., Aghamolaei, T., \& Safari-Moradabadi, A. Pregnant women's health literacy in the south of Iran. Journal of family \& reproductive health, 2017; 11(4), 211.

3. Fleary, S. A., Joseph, P., \& Pappagianopoulos, J. E. Adolescent health literacy and health behaviors: A systematic review. Journal of Adolescence, 2018;62, 116-127.

4. Hepburn M. The variables associated with health promotion behaviors among urban black women. J Nurs Scholarsh. 2018;50:353-66.

5. Yokokawa H, Fukuda H, Yuasa M, Sanada H, Hisaoka T, Naito $\mathrm{T}$. Association between health literacy and metabolic syndrome or healthy lifestyle characteristics among community-welling Japanese people. Diabetol Metab Syndr. 2016;30:1-9.

6. Berkman, N. D., Sheridan, S. L., Donahue, K. E., Halpern, D. J., \& Crotty, K. Low Health Literacy and Health Outcomes: An Updated Systematic Review. Annals of Internal Medicine, 2011; 155(2), 97. doi:10.7326/0003-4819-155-2-20110719000005

7. Sorensen, K., Van den Broucke, S., Fullam, J., Doyle, G., Pelikan, J., Slonska, Z., Brand, H. Health literacy and public health: A systematic review and integration of definitions and models. BMC Public Health, 2012; 12(1). doi:10.1186/14712458-12-80

8. Shieh, C., \& Halstead, J. A. Understanding the Impact of Health Literacy on Women's Health. Journal of Obstetric, Gynecologic \& Neonatal Nursing, 2009; 38(5), 601-612. doi:10.1111/j.1552-6909.2009.01059.x

9. United Nations Educational, Scientific and Cultural Organization, 2013

10. Tezcan, G. S. (2017). Temel Epidemoloji, Hipokrat Kitapevi. 1. Bask1

11. Yılmaz, E., \& Karahan, N. Gebelikte Sağlıklı Yaşam Davranışları Ölçeği'nin geliştirilmesi ve geçerlik güvenirliği. Cukurova Medical Journal, 2019; 44, 498-512.

12. Morin, M., Vayssiere, C., Claris, O., Irague, F., Mallah, S., Molinier, L., \& Matillon, Y. Evaluation of the quality of life of pregnant women from 2005 to 2015. European Journal of Obstetrics \& Gynecology and Reproductive Biology, 2017; 214, 115-130. doi:10.1016/j.ejogrb.2017.04.045

13. Zahra Karimi, F., Dadgar, S., Abdollahi, M., Yousefi, S., Tolyat, M., \& Khosravi Anbaran, Z. The relationship between minor ailments of pregnancy and quality of life in pregnant women. The Iranian Journal of Obstetrics, Gynecology and Infertility, 2017; 20(6), 8-21.
14. Ramírez-Vélez, R. Pregnancy and health-related quality of life: A cross-sectional study. Colombia Médica, 2011;42(4), 476481.

15. Can, R., Yılmaz, S. D., Cankaya, S., \& Kodaz, S. Gebelikte Yaşanan Sorunlar ve Yaşam Kalitesi İle İlişkisi. Sağllk ve Toplum, 2019; 29(2), 59-64

16. Giuse, N. B., Koonce, T. Y., Kusnoor, S. V., Prather, A. A., Gottlieb, L. M., Huang, L.-C., ... Stead, W. WInstitute of Medicine Measures of Social and Behavioral Determinants of Health: A Feasibility Study. American Journal of Preventive Medicine, 2017;52(2),

199-206. doi:10.1016/j.amepre.2016.07.033

17. Ohnishi, M., Nakamura, K., \& Takano, T. Improvement in maternal health literacy among pregnant women who did not complete compulsory education: policy implications for community care services. Health Policy, 2005;72(2), 157164. doi:10.1016/j.healthpol.2004.11.007

18. Eser E, Fidaner H, Fidaner C, Eser SY, Elbi H, Göker E. WHOQOL-100 ve WHOQOL-BREF'in psikometrik özellikleri. Psikiyatri Psikoloji Psikofarmakoloji (3P) Dergis. 1999;7(2):23-40

19. Fransen, M.P., Hopman, M.E., Murugesu, L. et al. Preconception counseling for low health literate women: an exploration of determinants in the Netherlands. Reprod Health 2018;15, 192 https://doi.org/10.1186/s12978-018-0617-1.

20. Akça, E., Gökyıldız Sürücü, Ş., Akbaş, M. Gebelerde Sağlık Algısı, Sağlık Okuryazarlığı ve İlişkili Faktörler. İnönü Üniversitesi Sağllk Hizmetleri Meslek Yüksekokulu Dergisi, 2020;8(3), 630-642

21. Taş, T. A., \& Akış, N. Sağlık okuryazarlığı. STED/Sürekli Tip Ë̆itimi Dergisi, 2016;25(3), 119-124.

22. Xuewei Chen, Jennifer L. Hay, Erika A. Waters, Marc T. Kiviniemi, Caitlin Biddle, Elizabeth Schofield, Yuelin Li, Kimberly Kaphingst \& Heather Orom Health Literacy and Use and Trust in Health Information, Journal of Health Communication, 2018:23:8, 724-734, DOI 10.1080/10810730.2018.1511658

23. Mazúchová, L., Kelčíková, S., \& Dubovická, Z. Measuring women's quality of life during pregnancy. Kontakt, 2018; 20(1), 31-36.

24. Daglar G, Bilgic D, Ozkan S A. Determinants of quality of life among pregnant women in the city centre of the Central Anatolia region of Turkey. Niger J Clin Pract 2020;23:416-24.

25. Schwarz, E. B., Smith, R., Steinauer, J., Reeves, M. F., \& Caughey, A. B. Measuring the effects of unintended pregnancy on women's quality of life. Contraception, 2008;78(3), 204210.

26. Balçık, P. Y., Taşkaya, S., \& Şahin, B. Sağlık okur-yazarlı̆̆ı. TAF Preventive Medicine Bulletin, 2014;13(4), 321-326.

27. Khaleghi, M., Amin Shokravi, F., \& Peyman, N. The relationship between health literacy and health-related quality of life in students. Iranian Journal of Health Education and Health Promotion, 2019; 7(1), 66-73.

28. Jenabi, E., Gholamaliee, B., \& Khazaei, S. Correlation between Health Literacy and Quality of Life in Iranian Menopausal Women. Journal of menopausal medicine, 2020;26(1), 34.

29. Kugbey, N., Meyer-Weitz, A., \& Asante, K. O. Access to health information, health literacy and health-related quality of life among women living with breast cancer: Depression and anxiety as mediators. Patient education and counseling, 2019;102(7), 1357-1363.

30. Wang, C., Kane, R. L., Xu, D., \& Meng, Q. Health literacy as a moderator of health-related quality of life responses to chronic disease among Chinese rural women. BMC women's health, 2015; 15(1), 1-8.

31. Okyay, P., Abacigil, F., Harlak, H., Evci Kiraz, E. D., Karakaya, K., Tuzun, H., ... \& Beser, EA new Health Literacy Scale: Turkish Health Literacy Scale and its psychometric properties: Pinar Okyay. The European Journal of Public Health, 2015: 25(suppl_3), ckv175-220. 